\title{
A Survey on Knowledge and Use of Passiflora Species in Cluj-Napoca, Romania
}

\author{
Paula BOBOC (OROS), Erzsebet BUTA, Ioana CRIȘAN and Maria CANTOR* \\ Faculty of Horticulture, University of Agricultural Sciences and Veterinary Medicine, Cluj-Napoca, \\ Romania, 3-5 Mănăştur St, 400372, Cluj-Napoca \\ *corresponding author: marcantor@yahoo.com
}

BulletinUASVM Horticulture 77(1) / 2020

Print ISSN 1843-5254, Electronic ISSN 1843-5394

DOI:10.15835/buasvmcn-hort: 2019.0012

\begin{abstract}
The present study aims the degree of the Passiflora genus knowledge on the population level in Cluj-Napoca, after imports of ornamental plants. The study was based on a short questionnaire with 8 questions, applied to a sample of randomly selected respondents. The results obtained demonstrated that Passiflora, although an exotic plant recently appeared in the local flower market, has been remarked and appreciated among the indigenous ornamental plants. From the data obtained, recommendations can be issued for introducing Passiflora genus in the assortment of flowering plants grown in Romania and to promote them among the local producers of ornamental plants in order to be marketed locally and nationally.
\end{abstract}

Keywords: passion flower, questionnaire, respondents, survey

\section{Introduction}

The etymology of Passiflora genus comes from the Latin "passio" which makes symbolic reference to the suffering of Jesus Christ and "flora" after Linnaeus's choice. Symbolic association with "The Passion of Christ" was performed for the first time in 1529 by Spanish conquistadors (Dhawan et al., 2004; Patel et al., 2011).

The genus Passiflora includes more than 560 flowering species (Shrestha et al., 2019) and is the most common of the Passifloraceae family, having the diversity center in South America (Bernacci et al., 2015). Plants of this genus are known for their ornamental value, but also for their therapeutic properties and the bioactive compounds they contain (Ramirez et al., 2019, DomínguezRodríguez et al., 2019). Fruits are widely accepted as important component of a healthy diet and adequate consumption could help to reduce a wide range of diseases (Thokchom et al., 2017). Passiflora plants are herbaceous, shrubs and often volatile plants with alternating leaves, sometimes simple, entire, lobed and/or palmate, sometimes compound, imparipinnate (Gontijo, 2000).

The current trends of the flower market in Romania involve diversifying the assortment with exotic species. Thus, the present study aims to estimate the popularity degree and the knowledge of the uses of Passifloraceae in Romania as a result of imports of ornamental flowering plants.

\section{Materials and methods}

In order to estimate better the degree of knowledge and use of Passiflora plants in the population of Cluj-Napoca, a non-nominal questionnaire was designed. Two methods were 
used to collect the data, namely applying the questionnaire in the online environment using the GoogleForms platform and through the personal approach of the respondent.

The questionnaire was applied to a sample of 273 randomly chosen persons. The participation of the respondents was anonymous and confidential.

The questionnaire was adapted according to the model used by Dan V. S. (2015), consisting of 9 short questions grouped into three parts. The time allowed for completing the questionnaire was 2-3 minutes. The answer variants fluctuated from a single answer, to multiple questions and open questions.

The first part of the questionnaire is represented by the first two questions. The questionnaire also contains a colorful, suggestive image with the most popular species among Passifloraceae, namely Passiflora caerulea.

The second part of the questionnaire contains four questions with direct reference to the popularity degree and uses of Passiflora.

The third part of the questionnaire contains questions that ask the demographic data of the respondents such as gender, age, educational level and an open question regarding the last form of education completed.

Questions were formulated in such a way to be understood even by people without specialized knowledge.

In the end, the data were interpreted cumulatively by means of graphs with the percentage results.

\section{Results and discussions}

The first question inquired based on the image presented: "Do you know the plant illustrated in the image bellow?". Of the total of 293 responses, $186(63.5 \%)$ were affirmative, respectively 108 (36.9\%) negative.

The first question was supplemented with a descriptive question, "If the answer is yes, what is its name?". 182 answers were obained, of which $179(98.4 \%)$ were considered correct. The answers considered "valid" were the following: "Passiflora" (here also included the answers of type "Pasiflora", "Passyflora" or "pasiflorae"), "Passiflora caerulea" (and "Passiflora caerulae"), "Passiflora incarnata", "Passion flower", "Passion fruit", "Maracuya".

The second question "Have you ever heard of Passiflora (Passion Flower)?" accumulated a total of 293 answers, of which 258 (88.1\%) were affirmative, the respondents heard the name Passiflora (Flower of passion), respectively 35 (11.9\%) of the answers stated that the respondents did not hear about Passiflora. Unexpectedly, the affirmative answers were higher compared to the 182 answers offered for the association of the plant in the image.

The third question asked "Have you ever had or did Passiflora plant at home/at work /etc.?" was mainly addressed to the respondents of the first two questions and recorded a total of 258 answers. Of the respondents, 95 (36.8\%) stated that they have ever had a Passiflora plant, 130 (50.4\%) mentioned that they never had this species, and $33(12.8 \%)$ do not know if they had ever. Those who responded that "I do not know" if they have ever had Passiflora are associated with those who do not recognized the plant, or are not interested in plants.

The fourth question referring to the knowledge degree of Passiflora plants, presented a series of five statements in which the respondents checked one of the variants: "Yes", "No" or "I don't know" highlighted in the respective column of Table 1.

- The statement "Passiflora is a flowering plant" received 193 (74.8\%) answers "Yes" (correct answer).

- The statement "Passiflora is a medicinal plant" received 102 (39.5\%) answers "Yes" (correct answer), where it is noted that there are connoisseurs respectively consumers of passiflora as a medicinal plant, but it is not sufficiently known in Romania.

- The statement "Passiflora produces edible fruits" obtained 162 (62.8\%) answers "Yes" (correct answer), where it was founded that the respondents known, have consumed the passion fruit or have heard of it, but at the local level it is not enough recognizable within the studied population.

- The statement "Passiflora is used for interior decoration" obtained 181 (70.2\%) answers "Yes" (correct answer). Seeing that a tropical climate plant, in Romania Passiflora resists over winter only in protected spaces, which makes it an interior decorative plant. Analyzing the answers received, an often large number of respondents answered correctly, "Yes", perhaps by associating it with its demands on temperature. 
Table 1. Centralized answers from the questionnaire of Passiflora knowledge

\begin{tabular}{|c|c|c|c|c|c|c|c|}
\hline \multirow[t]{2}{*}{ Answer versions } & \multirow{2}{*}{$\begin{array}{c}\text { Total } \\
\text { answers }\end{array}$} & \multicolumn{2}{|c|}{$\begin{array}{c}\text { Yes } \\
\text { (Right answer) }\end{array}$} & \multicolumn{2}{|c|}{$\begin{array}{c}\text { No } \\
\text { (Wrong answer) }\end{array}$} & \multicolumn{2}{|c|}{ I do not know } \\
\hline & & No. & $\%$ & No. & $\%$ & No. & $\%$ \\
\hline Question 1 & 293 & 186 & 63.5 & 108 & 36.9 & & \\
\hline Plant's name & 182 & 179 & 98.4 & 3 & 1.6 & & \\
\hline Question 2 & 293 & 258 & 88.1 & 35 & 11.9 & & \\
\hline Question 3 & 258 & 95 & 36.8 & 130 & 50.4 & 33 & 12.8 \\
\hline \multicolumn{8}{|l|}{ Question 4} \\
\hline 4.1 & 258 & 193 & 74.8 & 12 & 4.7 & 53 & 20.5 \\
\hline 4.2. & 258 & 102 & 39.5 & 58 & 22.5 & 98 & 38 \\
\hline 4.3. & 258 & 162 & 62.8 & 35 & 13.6 & 61 & 23.6 \\
\hline 4.4. & 258 & 181 & 70.2 & 28 & 11.2 & 48 & 18.6 \\
\hline 4.5 & 258 & 98 & 38 & 72 & 27.9 & 88 & 34.1 \\
\hline \multicolumn{8}{|l|}{ Question 5} \\
\hline White & 258 & 209 & 81.0 & 49 & 19.0 & & \\
\hline Yellow & 258 & 25 & 9.7 & 133 & 51.6 & & \\
\hline Blue & 258 & 193 & 74.8 & 65 & 25.2 & & \\
\hline Mauve & 258 & 208 & 80.6 & 50 & 19.4 & & \\
\hline Orange & 258 & 32 & 12.4 & 226 & 87.6 & & \\
\hline Pink & 258 & 69 & 26.7 & 189 & 73.3 & & \\
\hline Red & 258 & 76 & 29.5 & 182 & 70.5 & & \\
\hline \multicolumn{8}{|l|}{ Question 6} \\
\hline Flower shop & 258 & 156 & 60.5 & 102 & 39.5 & & \\
\hline Garden Center & 258 & 133 & 51.6 & 125 & 48.4 & & \\
\hline Supermarket & 258 & 112 & 43.4 & 146 & 56.6 & & \\
\hline DIY Store & 258 & 61 & 23.6 & 197 & 76.4 & & \\
\hline Online shop & 258 & 195 & 75.6 & 63 & 24.4 & & \\
\hline Question 7 & 293 & & & & & & \\
\hline Male & & 60 & 23.3 & & & & \\
\hline Female & & 198 & 76.7 & & & & \\
\hline Question 8 & 293 & & & & & & \\
\hline Under 20 years & & 7 & 2.4 & & & & \\
\hline 21-25 years & & 52 & 17.7 & & & & \\
\hline $26-35$ years & & 83 & 28.3 & & & & \\
\hline $36-45$ years & & 72 & 24.6 & & & & \\
\hline 46-55 years & & 44 & 15.0 & & & & \\
\hline $56-65$ years & & 21 & 7.2 & & & & \\
\hline Over 66 years & & 14 & 4.8 & & & & \\
\hline Question 9 & 293 & & & & & & \\
\hline Secondary school & & 3 & 1.0 & & & & \\
\hline High School & & 94 & 32.1 & & & & \\
\hline Post - High School & & 8 & 2.7 & & & & \\
\hline Bachelor's level & & 95 & 32.4 & & & & \\
\hline Master degree & & 82 & 28.0 & & & & \\
\hline Doctorate & & 9 & 3.1 & & & & \\
\hline Postgraduate studies & & 2 & 0.7 & & & & \\
\hline
\end{tabular}

- The statement "Passiflora is a garden plant" was appreciated with $72(27.9 \%)$ answers "No" (correct answer), it is likely that the respondents have seen passiflora used for the decoration of gardens or terraces, but in winter it must be protected in the vast majority of areas, which makes this plant not to be classified as a "garden plant" under the climatic conditions in Romania.
The fifth question concerned the level of knowledge of Passiflora flowers chromatics. The question was asked as follows: "If you know the flowers of Passiflora, choose the right colors for the flowers of these plants". Eight chromatic variants have been specified, all being correct variants, highlighted in the respective column of Table 1. It is likely that the answers to this question will be influenced by the color of the flowers presented in 
the image (Passiflora caerulea). Thus, the variant "White" obtained 209 (81.0\%) answers "Yes", the variant "Yellow" obtained 25 (9.7\%) answers "Yes", the variant "Blue" obtained 193 (74.8\%) answers "Yes", variant "Mauve" obtained 208 (80.6\%) answers "Yes", variant "Orange" obtained 32 (12.4\%) answers "Yes". The "Yellow" and "Orange" variants are found at Passiflora species from the spontaneous flora of tropical forests, which determined a lower rate of affirmative answers. The variant "Pink" obtained 69 (26.7\%) answers "Yes", the variant "Red" obtained 76 (29.5\%) answers "Yes", the variant "Burgundy" obtained 52 (20.2\%) answers "Yes".

The sixth question referring to the place where Passiflora is marketed and the answers were presented in the respective column of Table 1. $156(60.5 \%)$ respondents answered that they saw Passiflora in a flower shop; 133 (51.6\%) in a Garden Center; 112 (43.4\%) in the Supermarket and 195 (75.6\%) stated that they saw Passiflora in an online store.

Regarding the gender of the respondents, the highest percentage was represented by the female $(76,7 \%)$, the male gender representing only $23.3 \%$ of the total respondents.

Regarding the distribution of respondents by age groups the answers were presented in the respective column of Table 1 . It appears that the largest number of respondents, 83 (28.3\%), are part of the range of 26-35 years, followed closely by respondents aged $36-45$ years $(24.6 \%)$.

The analysis of responses about the last form of graduate education, the answers were presented in the respective column of Table 1 . A maximum number of 95 respondents graduated a college, at the bachelor's level, followed closely by 94 respondents who graduated high school.

In his research, Dan (2018), further the application of the knowledge questionnaire on Clematis species, reached the following conclusions: „Clematis are ornamental plants relatively known to us - about $50 \%$ of the people surveyed know these plants; the shrubs or evergreen species are not known or very little known and the cultivation of the Clematis in pots is very little known in the native landscape space".

Studies were also conducted to follow the degree of knowledge and usefulness of certain medicinal plants in various area. Gakuubi and Wanzala (2012) applied a study based on questionnaire into nomadic communities in Africa, in which they determined and analyzed the degree of knowledge and use of plants in the ethnoveterinary field in Ameru. The results showed that in the Fabaceae family $(16.67 \%)$ exists most plants used for preparation of ethnoveterinary treatments, followed by Solanaceae (12.5\%), Asteraceae and Euphorbiaceae (each containing 8.33\%), Lamiaceae (6.25\%), Apocynaceae and Boraginaceae each represented by a single species of plant.

Prakasha et Krishnappa (2006) evaluated the degree of knowledge using a questionnaire on the therapeutic effects for the species Lobelia, Vitex, Asparagus, Leucas, Hibiscus and Ocimum. The results showed that the indigenous people of Sringeri Taluk, India depend on these plants to treat skin diseases, itching and measles, being essential for modern medicine in those places.

\section{Conclusion}

Concerning the survey based on the questionnaire regarding the degree of Passiflora knowledge locally, and the analysis of centralized data obtained, the following conclusions are drawn:

Passiflora is an ornamental plant well known in the analyzed population, $63.5 \%$ of the total respondents said that they known the plant. Although the medicinal properties of the Passiflora plant are quite promoted, a relatively small percentage of respondents are aware of this. In contrast, over $60 \%$ of the respondents know that the fruit of Passiflora is edible.

These high percentages highlight the fact that Passifora plants are noted and arouse curiosity among people, due to its special flowers and the multiple possibilities of use and decoration that the respondents largely know.

Regarding the commercialization of Passiflora in Romania, there are affirmative answers for each type of commercial unit analyzed, with high percentage about online stores and flower shops, which indicates imports of these plants made on a large scale.

It is recommended to introduce Passiflora genus in the assortment of flowering plants grown in Romania and to promote them among the local producers of ornamental plants in order to be marketed locally and nationally. 


\section{References}

1. Bernacci LC, Cervi AC, Milward-de-Azevedo MA, Nunes TS, Imig DC, Mezzonato AC (2015). Passifloraceae in Lista de Espécies da Flora do Brasil. Jardim Botânico do Rio de Janeiro.

2. Dan VS (2015). Suitability of certain Clematis species to contained cultivation and their use in landscape gardening. Ph.D. Thesis, University of Agricultural Sciences and Veterinary Medicine, Cluj-Napoca, 61-62.

3. Dan VS, Buta E, Cotoz A, Sestras R (2018). Inventory, survey of cognition and study of landscaping possibilities for Clematis species in Cluj-Napoca, Romania. ProEnvironment 11: $26-31$.

4. Domínguez-Rodríguez G, García MC, Plaza M , Marina ML (2019). Revalorization of Passiflora species peels as a sustainable source of antioxidant phenolic compounds. Science of The Total Environment, 696.

5. Gakuubi MM, Wanzala W (2012). A survey of plants and plant products traditionally used in livestock health management in Buuri district, Meru County, Kenya. Journal of ethnobiology and ethnomedicine, 8: 39.
6. Gontijo SC (2000). Tissue culture and phytochemical studies of Podophyllum, Diphylleia and Passiflora species, Ph.D. thesis, University of Nottingham, 41.

7. Prakasha HM, Krishnappa M (2006). People's knowledge on medicinal plants in Sringeri Taluk, Karnataka. Indian journal of traditional knowledge 3: 353-357.

8. Ramirez V, Arango SS, Maldonado ME, Uribe D, Aguillon J., Quintero JP, Loango N (2019). Biological activity of Passiflora edulis f. Flavicarpa ethanolic leaves extract on human colonic adenocarcinoma cells. Journal of Applied Pharmaceutical Science 9(02): 64-07.

9. Shrestha B, Weng M-L, Theriot E C, Gilbert LE, Ruhlman TA, Krosnick SE, Jansen RK (2019). Highly accelerated rates of genomic rearrangements and nucleotide substitutions in plastid genomes of Passiflora subgenus Decaloba, Molecular Phylogenetics and Evolution 138: 53-64.

10. Thokchom R, Mandal G (2017). Production preference and importance of passion fruit (Passiflora edulis): a review. Journal of Agricultural Engineering and Food Technology, 4(1): 27-30. 